\title{
Haemozoin Deposits Influence Fetal Weight of Pregnant Mice Infected by Plasmodium berghei
}

\section{Deposit Hemozoin Mempengaruhi Berat Janin Mencit Bunting yang Diinfeksi Plasmodium berghei}

\author{
Desy Andari ${ }^{1}$, Loeki E Fitri', Karyono Mintaroem ${ }^{3}$ \\ ${ }^{1}$ Departement of Histology, Faculty of Medicine University of Muhamadiyah Malang \\ ${ }^{2}$ Departement of Parasitology Faculty of Medicine University of Brawijaya Malang \\ ${ }^{3}$ Departement of Pathology Faculty of Medicine University of Brawijaya Malang
}

\begin{abstract}
Low birth weight is commonly attributed to malaria in pregnancy, but the cellular and molecular mechanisms that underlie this are incompletely understood. Many of hormones and cytokines are dysregulated in this case and it alters histological structure of placenta which known as placenta malaria. In the placenta malaria, there is an accumulation of infected erythrocytes, macrophages and malarial pigment (haemozoin). This study was conducted to compare the levels of plasma and placenta interferon-gamma (IFN- $\gamma$ ) and haemozoin deposit in pregnant mice that infected by Plasmodium berghei (treatment group) to the normal pregnant mice (control group) and its association with fetal weight. This in vivo experimental laboratory study used pregnant Balb/c mice which divided to control and treatment group. Placentas were staining with Haematoxylin-Eosin (HE) for haemozoin deposits examination. Plasma and placenta levels of IFN- $y$ examined with ELISA assay. Levels of IFN- $\gamma$ were higher in plasma than placenta and slightly higher in treatment group than control group, but the differences were not significant $(p>0,05)$. Fetal weight of treatment group was lower than those of control group $(p=0,002)$ however there was no correlation between fetal weight and plasma as well as placenta levels of IFN- $\gamma$ $(p>0,05)$. Haemozoin deposit was found only in treatment group and influenced weight of fetuses $($ Spearman $=-0,633$, $p=0,006)$. Weights of fetuses are more interfered by haemozoin deposit and seemly not by plasma and placenta levels of IFN- $y$ during malaria infection.
\end{abstract}

Keywords: Fetal weight, gamma interferon, haemozoin, malaria, placenta

\section{ABSTRAK}

Berat badan lahir rendah sering terjadi pada kehamilan dengan malaria, namun mekanisme seluler dan molekuler yang mendasarinya belum sepenuhnya dipahami. Banyak hormon dan sitokin yang mengalami perubahan pada kasus ini. Perubahan struktur histologi plasenta akibat kehamilan dengan malaria dikenal dengan malaria plasenta. Pada malaria plasenta terjadi akumulasi eritrosit yang terinfeksi, makrofag dan pigmen malaria (hemozoin). Penelitian ini bertujuan membandingkan kadar interferon gamma (IFN- $\gamma$ ) plasma dan plasenta serta deposit hemozoin antara mencit bunting yang diinfeksi malaria dan mencit bunting normal dan mengetahui hubungannya dengan berat badan janin. Penelitian eksperimental laboratorium ini menggunakan mencit bunting jenis Balb/c yang dibagi menjadi kelompok perlakuan dan kelompok kontrol. Plasenta mencit kemudian diwarnai dengan Haematoxylin-Eosin (HE) untuk pemeriksaan deposit hemozoin, sedangkan kadar IFN- $\gamma$ plasma dan plasenta diperiksa dengan metoda ELISA. Kadar IFN- $\gamma$ plasma lebih tinggi daripada kadar IFN- $\gamma$ plasenta dan kadar pada kelompok perlakuan sedikit lebih tinggi daripada kelompok kontrol, namun perbedaannya tidak signifikan $(p>0,05)$. Berat badan janin kelompok perlakuan lebih rendah daripada berat badan janin kelompok kontrol $(p=0,002)$ namun tidak ditemukan hubungan dengan kadar IFN- $\gamma$ baik di plasma maupun plasenta $(p>0,05)$. Deposit hemozoin hanya ditemukan pada kelompok perlakuan dan sangat berpengaruh terhadap berat badan janin (Spearman=-0,633, $p=0,006$ ). Berat badan janin lebih dipengaruhi oleh deposit hemozoin dan tampaknya tidak dipengaruhi oleh kadar IFN- $p$ plasma maupun plasenta pada infeksi malaria.

Kata Kunci: Berat janin, hemozoin, interferon-gamma, malaria, plasenta

Jurnal Kedokteran Brawijaya, Vol. 28, No. 4, Agustus 2015; Korespondensi: Desy Andari. Departement of Histology Faculty of Medicine University of Muhamadiyah Malang, Jl. Bendungan Sutami 188 A Malang 65145 Tel. (0341) 552443 Email:desy.qruezt@gmail.com 


\section{INTRODUCTION}

Malaria is a significant health and development concern facing millions of people and its control and prevention are part of the United Nations Millenium Development Goals (MDGs) (1). According to Annual Parasite Incidence some areas in Indonesia are still in high level of malaria and the other areas are in moderate and low level (2). It is a major public health program in Indonesia with 6 million clinical cases and 700 deaths each year (3). Malaria in pregnant women could cause severe anemia to the mother (4) that will lead to morbidity in fetus such as low birth weight (5), preterm delivery and died after birth (6).

Malaria in pregnancy has a particular feature that is accumulation of infected red blood cells (iRBC) within placenta (7) which is referred as placental malaria (PM). Placental malaria (PM) revealed a number of abnormalities to placental tissue such as excess of fibrinoid deposits and malarial pigment deposits (haemozoin) (8). Accumulation of iRBC in placenta related to placenta inflammation by activated placental macrophage that could induce placental damage through releasing inflammatory cytokines such as Tumour Necrosis Factor-Alfa (TNF- $\alpha$ ), Interferon-gamma (IFN- $\gamma$ ) (9), Interleukin-beta (IL- $\beta$ ) and Interleukin-2 (IL-2) (10). Interferon-gamma (IFN- $\gamma$ ) as inflammatory cytokine was suggested as part of carefully regulated cytokine network. The elevated expression of IFN- $\gamma$ in multigravid women with PM-negative suggests that this cytokine is important in controlling the parasitemia in placenta (11). To further investigate the associations among the haemozoin deposit, IFN- $\gamma$ and fetal weight, we conducted an experimental study to analyze the level of IFN- $\gamma$ in plasma and placental tissue, the histopathological change in placenta (haemozoin deposit) and weight of the fetus in pregnant mice that infected with Plasmodium berghei.

\section{METHOD}

\section{Research Design and Samples}

An in vivo experimental laboratory study was conducted by comparing data obtained from two groups of Balb/c strain pregnant mice those were a study group which infected by Plasmodium berghei on ninth day post mating and a control group (non-infected pregnant mice). The pregnant mice were mice of 20-30 grams weight and $13-$ 15 weeks old. The mice were evaluated daily, especially their body weight and pregnancy symptoms also the parasitemia of the study group. On the day 18 post mating the mice were terminated.

\section{Ethical Considerations}

Ethical clearance was provided by the committees of research of the Medical Faculty Brawijaya University (No. 104/EC/KEPK-S2/03/2013). All animals in was treated well during this research and buried after research.

\section{Animals and Parasites}

The BALB/c mice were obtained from Gadjahmada University and maintained in conventional housing at the Parasitology Laboratorium Faculty of Medicine Brawijaya University. Infection experiments were performed in adult females, between 13-16 weeks of age. Plasmodium berghei ANKA was provided by Parasitology Laboratory Brawijaya University. All animals were fed with regular diet and all procedures were in accordance with national regulations on animal experimentation and welfare.

Pregnancy Experimental Infection and Isolation of the

\section{Placenta and the Fetus}

Pregnant mice were intra-peritoneally (IP) infected at day9 pregnancy with $10^{6} \mathrm{iRBC}$, and parasitemia was recorded every other day. Non-infected pregnant females were used as controls in pregnancy infection experiments as appropriate. Part of the pregnant females (both infected and controls) were caesarian section at day-18 of pregnancy to placenta pathology observation and the fetus were scaled using analytical scale (Mettler AE 50).

\section{Tissue Preparation and Histopathological Analysis}

Placentas from infected and non-infected females were treated in a similar way. Placentas were separated in two halves, one half was fixed in formaldehyde for further tissue processing (sectioning) and the other half collected in freeze for measurement of IFN- $\gamma$ level. Paraffinembedded non-consecutive placenta sections were stained with Haematoxillin-Eosin (HE) and immunohistochemically using purified anti-mouse Interferon-gamma (BioLegend) and examined under a light microscope (Olympus CX 21 LED FSI).

\section{Measurements of Haemozoin Deposit and IFN- $\gamma$}

Placental sections were stained with $\mathrm{H}-\mathrm{E}$ and examined under light microscope under supervised of Anatomical Pathologist. Placental plasma and tissue were measured using IFN- $\gamma$ Quantikine ELISA (Enzyme Immuno Assay) Inc From BioLegend, catalog 505801.

\section{Statistical Analysis}

Analyses were performed using SPSS 16 software. Lavene's test was used to see the distributed data and Saphiro wilk was used for evaluated the data homogeneity. Statistical differences between groups of mice used in this study were evaluated by t test for normally distributed data. Correlation test was done using Pearson and Spearman.

\section{RESULTS}

\section{Levels of IFN-y in Plasma and Tissue Placentas}

There were eight samples of control group and nine samples of treatment group. All data have been test for normality and homogeneity (Saphiro Wilk>0,05). Levels of IFN- $\gamma$ were higher in plasma than in tissue placentas and slightly higher in treatment group than control group, however the differences were not significant both in plasma $(p=0,807)$ and tissue $(p=0,424)$ (Figure 1$)$.

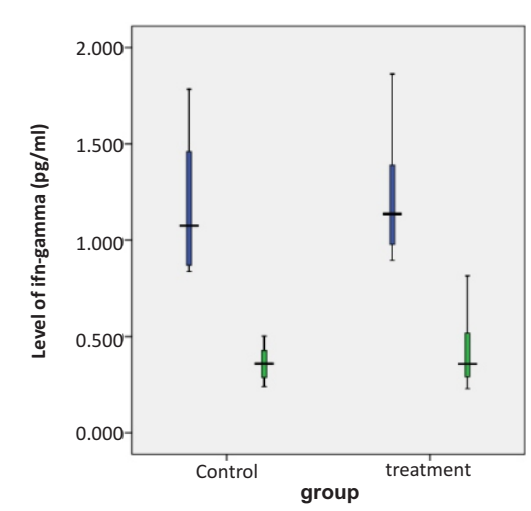

Place $\square$ Plasma
$\square$ Tissue

Figure 1. Levels of IFN- $\gamma$ in plasma and placentas of control group and treatment group

Note: There was no significant difference between two groups either in plasma or placentas' tissue 
We also found increasing of trophoblast expressing IFN- $\gamma$ in placenta of treatment group. Figure 2 showed that the expressions of IFN- $\gamma$ from the treatment group are more than the control group.

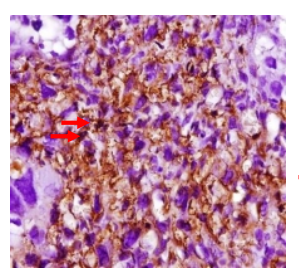

(A)

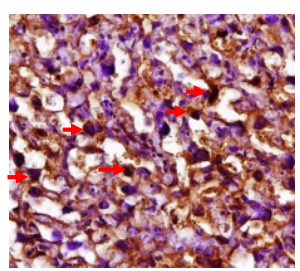

(B)
Figure 2. Interferon- $\gamma$ expression in placental tissue of control group (A) and treatment group (B)

Note: Immunohistochemistry analysis of placentas were stained with purified anti-mouse Interferon-gamma. Arrowhead show a trophoblast that expressed IFN- $\gamma$ (brown cytoplasm) (400x magnification).

\section{Haemozoin Deposit}

Haemozoin deposits were found in all samples of treatment group and none of the control group shows haemozoin deposit. Haemozoin was variable in treatment group, from less than $10 \%$ up to more $40 \%$ per high-power field.

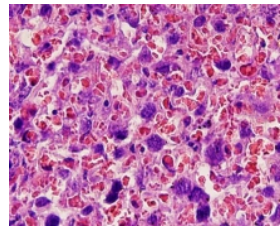

(A)

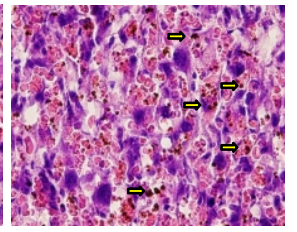

(B)
Figure 3. HE stained placentas from control group (A) and treatment group (B)

Note: Arrowhead shows haemozoin deposits in treatment group. (HE, 400x magnification).

\section{Fetal Weight}

Mean fetal weight in this study was $0,9392 \mathrm{~g}$ for the control group and $0,6480 \mathrm{~g}$ for the treatment group. Using independent $t$ test there was a significant differences $(p=0,002)$.

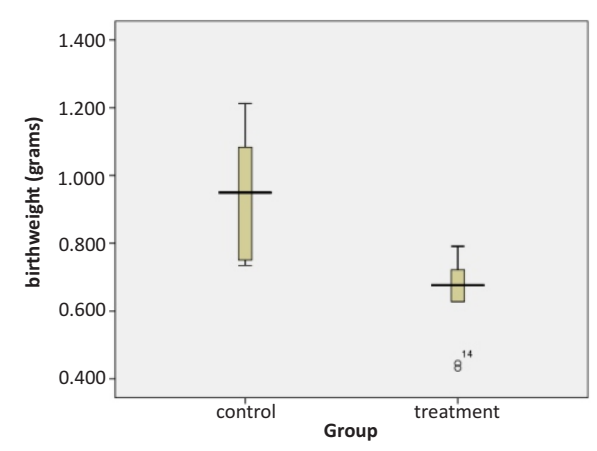

Figure 4. Fetal weight of control group and treatment group Note: Weight of fetuses were significantly higher in control group than the treatment group
Correlation Test between Level of IFN- $\gamma$, Haemozoin Deposits and Fetal weight

There was no correlation between levels of IFN- $\gamma$ and weight of fetus. Both were not significant $(p>0,05)$. Table below shows the data.

Table 1. Correlation between level of IFN- $\gamma$, haemozoin deposits and fetal weight

\begin{tabular}{llrrrr}
\hline & $\begin{array}{c}\text { Fetal } \\
\text { weight }\end{array}$ & $\begin{array}{c}\text { IFN- } \gamma \text { in } \\
\text { plasma }\end{array}$ & $\begin{array}{c}\text { IFN- } p \text { in } \\
\text { plasenta }\end{array}$ & $\begin{array}{c}\text { Haemozoin } \\
\text { deposits }\end{array}$ \\
\hline Fetal weight & Correlation Coefficient & 1 & 0,081 & $-0,330$ &,$- 705^{* *}$ \\
& Sig. (2-tailed) & & 0,758 & 0,196 &, $002^{*}$ \\
N & 17 & 17 & 17 & 17 \\
\hline
\end{tabular}

**Correlation is significant at the 0.05 level (2-tailed).

Levels of IFN- $\gamma$ plasma and tissue have a weak correlation (Pearson Correlation $=0,225$, sig $=0,335$ ). (Data was not shown).

There was a negative strong correlation between haemozoin deposits and weight of fetus (Spearman=$0,705, p=0,002$ ) and this correlation was very significant.

\section{DISCUSSION}

Plasma levels of IFN- $\gamma$ were higher than tissue level of IFN- $-\gamma$ in this study, and the level of IFN- $\gamma$ in treatment group was slightly higher than the control group. IFN- $\gamma$ is one of the pro-inflammatory cytokine that should be increased if there is an inflammatory process including malarial infection $(11,12)$. IFN- $\gamma$ expression in response to soluble malarial antigen stimulation tended to be exclusive. PMpositive primi/secundigravid produced high level of IFN- $\gamma$ and PM-positive multigravid produced low level. The elevated expression of IFN- $\gamma$ by PM-negative multigravid compared with PM-negative primi/secundigravid suggests that this cytokine is likely to be important in the control of parasitemia in the placenta. The lack of IFN- $\gamma$ production by PM-positive multigravid especially after stimulation with malarial antigen, lends further support to this hypothesis. Also, primi/secundigravid cells mounted a slightly elevated IFN- $\nu$ response in the presence of PM infection, yet they were unable to clear their parasitemia. Taken together, these data suggest that women whose are committed to constitutively produce high levels of IFN- $\gamma$ (i.e., PM-negative multigravidae) can effectively control parasitemia upon exposure, and those who are low producers tend to be susceptible to PM (11).

Different result has shown by Barasa et al that used female baboons to measure IFN- $\gamma$. In this study, the mean concentrations of IFN- $\gamma$ cytokine were significantly lower $(P<0,05)$ in sera samples from $P$. knowlesi infected placentas $(21,2 \mathrm{pg} / \mathrm{mL})$ than concentrations in sera from uninfected placentas $(68,3 \mathrm{pg} / \mathrm{mL})$. Even their result is not supporting other, Barasa et al agreed that IFN- $\gamma$ has a crucial protective role against PM since reduced levels of this cytokine were detected in the malaria infected placentas. Cytokine responses in the placentas were significantly altered following the onset of PM leading to a shift in immunity (13).

Many studies show that pro-inflammatory Th-1 cytokines are crucial determinants of malaria disease states. In 
addition to acute-phase, the production of which is induced rapidly by parasite toxins, IFN- $\gamma$ levels can increase very early during malaria. Human NK cells also become activated early during malaria and are activated rapidly by parasites in vitro, which requires direct contact of infected red blood cells with NK cells and results in IFN- $\gamma$ production. (14). Increasing of IFN- $\gamma$ in early phase of malaria also shown by study from Poovassery \& Moore (15). IFN- $\gamma$ was significantly higher in infected pregnant mice on day 9 and decline on day 10 when the infected pregnant mice begin to abort. IFN- $\gamma$ levels did not differ between the infected pregnant mice and uninfected.

Weight of fetuses are significantly different between control and treatment group, this is supporting by many previous studies $(6,11,16)$. But it is seemly not interfered just by IFN- $\gamma$ levels. Even the levels of IFN- $\gamma$ in plasma or tissue placentas from treatment group were slightly higher than the control group, they have no significantly correlation with fetal weight. This data supporting previous study from Rogerson et al (9) that conclude TNF$\alpha$ but not IFN- $\gamma$ may be implicated in impaired fetal growth (study in Malawian women).

Inflammatory infiltration of the intervillous spaces was associated with a reduction in birth weight, particularly when mononuclear cells were highly increased. The presence of massive mononuclear intervillositis in the placenta also was associated with a 4-fold increase in risk of low birth weight. These findings strongly indicate that that placental insufficiency attributable to physical blockage by infected red blood cells may not be the only, or indeed even the most important mechanism mediating intra uterine growth retardation. This massive monocyte infiltration of the intervillous space is likely to be a source of cytokines including IFN- $\gamma$ which is considered detrimental to pregnancy in association to poor pregnancy outcomes (5).

The presence of haemozoin deposits in placental tissue

\section{REFERENCES}

1. United Nations International Children's Emergency Fund. An Introduction to Malaria. Kanada: United Nations International Children's Emergency Fund: 2007.

2. Kementerian Kesehatan Republik Indonesia. Buletin Malaria: Epidemiologi Malaria di Indonesia. Jakarta: Kementerian Kesehatan Republik Indonesia; 2011: hal. 7-21.

3. Dale $\mathrm{P}$, Sipe $\mathrm{N}$, Anto $\mathrm{S}$, et al. Malaria in Indonesia: $A$ Summary of Recent into its Environmental Relationships. Southeast Asian Journal of Tropical Medicine and Public Health. 2005: 36(1): 1-13.

4. Shulman CE, Marshall T, Dorman EK, et al. Malaria in Pregnancy: Adverse Effects on Haemoglobin Levels and Birthweight in Primigravidae and Multigravidae. Tropical Medicine and International Health. 2001; 6(10): 770-778.

5. Menendez C, Ordi J, Ismail MR, Ventura PJ, et al. The Impact of Placental Malaria on Gestational Age and Birth Weight. The Journal of Infectious Diseases 2000; 181: 1740-1745.

6. Neres R, Marinho CRF, Goncalves LA, Catarino MB, decrease the fetal birth weight significantly in this study. This finding supporting the previous research from Menendez et al (2000) that the association between haemozoin and birth weight was not affected by the location of the pigment, except in the case of the syncytiotrophoblast. Haemozoin in this site may reflect a severe infection, possibly accompanied by inflammation, in the layer that is in closest contact with fetal circulation and this haemozoin possibly has the greatest potential to interfere with intrauterine growth (5). Another research in human also shows that women with high amount of haemozoin had babies with lower birth weights and lower level of haemoglobin, which is haemoglobin tends to decrease with the amount of haemozoin in the placenta (17). This study finding concurred that placental malaria alters placenta histology such as haemozoin deposit and disturbs many cytokines in pregnant mice including IFN- $\gamma$. Placental malaria also interfere fetal weight by the presence of haemozoin deposits, but there is no correlation between plasma and placenta IFN- $\gamma$ with fetal weight in this study.

\section{CONFLICT OF INTERESTS}

The authors declare that there is no conflict of interests.

\section{ACKNOWLEDGMENTS}

The authors would like to thank the University of Brawijaya, Malang, Indonesia for financial support of this project. We express our appreciation to our partners in study of placental malaria: Zanibur Rahmah S.Si, M.Si; Yuliyanik, Amd.Keb.SKM; dr. Sujarot Dwi Sasmito, Nur Fahma Pradiptasari, Adila Ulfiati, Bougenvil Ungu, the staff of the Parasitology Laboratory Faculty of Medicine University of Brawijaya for the animal housing and Surya Kurnia Hayati, Ssi from Biomedical Laboratory Faculty of Medicine University of Brawijaya for her good assistance in ELISA assay and immunohistochemistry.

and Penha-Goncalves C. Pregnancy Outcome and Placenta Pathology in Plasmodium berghei ANKA Infected Mice Reproduce the Pathogenesis of Severe Malaria in Pregnant Women. PLoS ONE. 2008; 3(2): e1608.

7. Duffy PE and Fried M. Plasmodium falciparum Adhesion in the Placenta. Current Opinion in Microbiology. 2003; 6(4): 371-376.

8. Walter PR, Garin Y, and Blot P. Placental Pathologic Changes in Malaria: A Histologic and Ultra-structural Study. The American Journal of Pathology. 1982; 109(3): 330-342.

9. Rogerson SJ, Brown HC, Pollina E, et al. Placental Tumor Necrosis Factor Alpha but Not Gamma Interferon Is Associated with Placental Malaria and Low Birth Weight in Malawian Women. Infection and Immunity. 2003; 71(1): 267-270.

10. Rogerson SJ, Mwapasa V, and Meshnick SR. Malaria in Pregnancy: Linking Immunity and Pathogenesis to Prevention. The American Journal of Tropical Medicine and Hygiene. 2007; 77(Suppl 6): 14-22.

11. Moore JM, Nahlen BL, Misore A, Lal AA, and Udhayakumar V. Immunity to placental Malaria. I. Elevated Production of Interferon-g by Placental Blood 
Mononuclear Cells Is Associated with Protection in an Area with High Transmission of Malaria. The Journal of Infectious Diseases. 1999; 179(5): 1218-1225.

12. Othoro C, Moore JM, Wannemuehler KA, et al. Elevated Gamma Interferon-Producing NK Cells, CD45RO Memory-Like T Cells, and CD4 T Cells Are Associated with Protection against Malaria Infection in Pregnancy. Infection and Immunity. 2008; 76(4): 1678-1685.

13. Barasa M, Ng'ang'a ZW, Sowayi GA, et al. Cytokine Expression in Malaria-Infected Non-Human Primate Placentas. Open Veterinary Journal. 2012; 2: 58-64.

14. Schofield L and Grau GE. Immunological Processes in
Malaria Pathogenesis. Nature Reviews Immunology. 2005; 5(9): 722-735.

15. Poovassery J and Moore M. Association of MalariaInduced Murine Pregnancy Failure with Robust Peripheral and Placental Cytokine Responses. Infection and Immunity. 2008; 77(11): 4998-5006.

16. Fried M, Muga RO, Misore AO, and Duffy PE. Malaria Elicits Type 1 Cytokines in the Human Placenta: IFN-g and TNF-a Associated with Pregnancy Outcomes. The Journal of Immunology. 1998; 160(5): 2523-2530.

17. Sarr D, Aldebert D, Marrama L, et al. Chronic Infection during Placental Malaria is Associated with UpRegulation of Cycloxygenase-2. Malaria Journal. 2010; 9: 45. 